\title{
Correlations Between Endothelial Dysfunction and Cerebral Imaging in Migraine
}

\author{
Migrende Endotel Disfonksiyonu ve Serebral Görüntüleme ile Korelasyonu
}

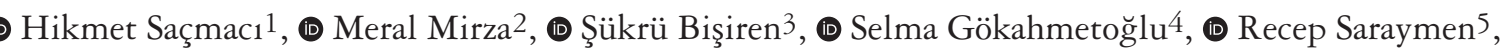
(1) Abdullah Talaslıoğlu²

\author{
${ }^{1}$ Bozok University Faculty of Medicine, Department of Neurology, Yozgat, Turkey \\ ${ }^{2}$ Erciyes University Faculty of Medicine, Department of Neurology, Kayseri, Turkey \\ ${ }^{3}$ Erciyes University Faculty of Medicine, Department of Radiology, Kayseri, Turkey \\ ${ }^{4}$ Erciyes University Faculty of Medicine, Department of Microbiology, Kayseri, Turkey \\ 5 Erciyes University Faculty of Medicine, Department of Biochemistry, Kayseri, Turkey
}

\begin{abstract}
Objective: Despite its high prevalence, the basic pathophysiologic mechanism of migraine is still poorly understood. Our aim was to research endothelial dysfunction in patients with recently diagnosed episodic migraine, and to determine whether there was a correlation between endothelial dysfunction and white matter lesions (WMLs) on magnetic resonance imaging (MRI).

Materials and Methods: This study was conducted between 2013 and 2014. A total of 51 patients and 27 healthy controls were included in the study. MRI was performed in the patient group. Blood samples were collected to investigate serum level of lipids, thyroid hormones, asymmetric dimethyl arginine, and endothelin levels in the patient and control groups. Homeostasis model assessment = insulin resistance factor and brachial artery index flow-mediated dilatation (FMD) were investigated in both groups.

Results: WMLs on MRI were present in 40 patients with migraine. FMD was low in patients with migraine $(\mathrm{p}=0.021)$. There was a negative correlation between the severity of migraine headache and FMD. A positive correlation was seen between severity of headache and WMLs ( $\mathrm{p}=0.001)$. The other blood sample concentrations in both the case and control groups were not significantly different. When the blood parameters were evaluated with MRI lesion load, there was a positive correlation with age, cholesterol, low-density lipoprotein, body mass index and triglyceride, and contrary to expectations, there was no relationship with homocysteine. However, there was a significant correlation between insulin resistance and lesion load ( $\mathrm{p}<0.03$ ).

Conclusion: In this study, especially in patients with episodic migraine with WMLs, FMD as a marker for endothelial dysfunction was found to be statistically significant. This finding contributes to the pathogenesis of migraine. An endothelial therapeutic drug could be considered as an option, especially in patients who need prophylaxis.
\end{abstract}

Keywords: Flow-mediated dilatation, white matter lesions, migraine, endothelin

$\ddot{\mathbf{O z}}$

Amaç: Yüksek prevalans oranına rağmen migren patofizyolojisi halen anlaşılamamıştır. Bu çalışmada, yeni tanı almış epizodik migren hastalarında endotel disfonksiyonunun araştırılması, bulguların sağlıklı kontrollerle karşılaştırılması ve manyetik rezonans görüntülemede (MRG) beyaz cevher lezyonları (BCL) oluşmuş ise bu lezyonlar ile endotel disfonksiyonu arasında bir korelasyon olup olmadığının değerlendirilmesi amaçlanmıştır.

Gereç ve Yöntem: Bu çalışma 2013 ve 2014 yılları arasında yürütülmüştür. Çalışmaya toplam 51 hasta ve 27 sağlıklı kontrol alındı. Hasta grubunda MRG yapıldı. Hasta ve kontrol grubunda, kan lipitleri, tiroid hormonları, asimetrik dimetil arjinin ve endotelin seviyeleri için kan numuneleri toplandı. Her iki grupta insülin direnci = homeostasis model değerlendirmesi ve brakiyal arter indeksi flow-aracılı dilatasyon (FMD) araştırıldı.

Bulgular: Migrenli 40 hastada MRG'de BCL mevcuttu. Migren hastalarında FMD düşüktü ( $\mathrm{p}=0,021$ ). Migren baş ağrısı şiddeti ile FMD arasında negatif korelasyon bulundu. Baş ağrısı şiddeti ile BCL'ler arasında pozitif bir ilişki görüldü ( $\mathrm{p}=0,001$ ). Hasta ve kontrol grubunda belirtilen belirteçlerin konsantrasyonları arasında istatistiksel olarak anlamlı farklılık görülmedi. Kan parametreleri ile MRG lezyon yükü korelasyonuna bakıldığında yaş, kolesterol, düşük yoğunluklu lipoprotein, vücut kitle indeksi ve trigliserid düzeyi ile pozitif korelasyon saptandı ve beklenenin aksine homosistein düzeyi arasında ilişki yoktu. Bununla birlikte, insülin direnci ve lezyon yükü arasında anlamlı bir ilişki vardı $(\mathrm{p}<0,03)$.

Address for Correspondence/Yazışma Adresi: Hikmet Saçmacı MD, Bozok University Faculty of Medicine, Department of Neurology, Yozgat, Turkey Phone: +90 5052621012 E-mail: hsacmaci@hotmail.com ORCID ID: orcid.org/0000-0003-1480-0562

Received/Geliş Tarihi: 05.05.2018 Accepted/Kabul Tarihi: 26.08.2018

${ }^{\circ}$ Copyright 2019 by Turkish Neurological Society

Turkish Journal of Neurology published by Galenos Publishing House. 
Öz

Sonuç: Bu çalışmada özellikle BCL’li epizodik migrenli hastalarda, endotel disfonksiyonu için bir belirteç olan FMD'nin istatistiksel olarak anlamlı olduğu bulunmuştur. Bu bulgu migren patogenezine katkıda bulunabilir. Özellikle profilaksiye ihtiyaç duyan hastalarda endotel düzeyinde tedavi edici bir farmakoterapi seçenek olarak düşünülebilir.

Anahtar Kelimeler: Flow-arac1lı dilatasyon, beyaz cevher lezyonları, migren, endotelin

\section{Introduction}

Migraine is a primary neurologic disorder characterized by headache attacks (1). It is generally unilateral, pulsating in nature, and the frequency of pain decreases with age (2). For many decades, the major contributing factor was thought to be cerebral and meningeal vasodilation (VD). Although there is a strong correlation between migraine pathology and the vascular system, few studies have claimed that VD does not contribute to migraine.

Studies have shown that migraine damages endotheliumdependent VD, and it has been reported that recurrent attacks cause an increase in white matter lesions (WMLs), trigger migraine aura, and raise the frequency of migraine attacks (3). It is believed that this process occurs as a result of recurrent ischemic damage during migraine, but there are various opinions on this subject (4).

Endothelial dysfunction is a pathologic condition characterized by the complete absence of endothelium-induced VD, along with an increase in endothelin-releasing vasoconstrictor substances, and is an important endpoint of vascular disease (5). Another reason of endothelial dysfunction is endothelial activation through proinflammatory and procoagulant factors. This is the most important result of all vascular diseases and atherogenesis (6). Thus far, there have been controversial results in various studies investigating endothelial dysfunction. Among the several non-invasive methods of measuring endothelial function, flowmediated dilatation (FMD) is the most widely adopted. FMD is a method of assessing flow-induced endothelial VD in the brachial artery (7). The role of neurogenic inflammation, endothelial dysfunction, and oxidative stress in migraine pathogenesis is investigated by means of FMD (8). Previous studies using FMD found a decrease in FMD levels in a relatively small group of patients (9).

One of the other causes of endothelial dysfunction is insulin resistance, and there is a relationship between migraine and insulin metabolism. Insulin receptor activation triggers migraine attacks. Recently, it has been shown that there are important associations in the pathogenesis of the insulin receptor gene and migraine. Insulin resistance lead to cell damage in migraineurs. Insulin resistance, abnormal fibrinolysis, systemic inflammation, and platelet aggregation cause irregularity in vascular endothelial function (10).

In this study, the presence of endothelial dysfunction and insulin resistance was investigated in patients with migraine who were newly diagnosed and had not received prophylactic treatment. This study was aimed to evaluate the relation between WMLs, serum biomarkers, and endothelial dysfunction in episodic migraineurs.

\section{Materials and Methods}

\section{Patients}

This study was conducted prospectively between 2013 and 2014. A total of 51 (8 males, 43 females) patients and 27 (5 males, 22 females) healthy controls were included in the study. The patients and healthy controls were randomly selected. Migraine-type headache without aura was detected and diagnosed. This study was approved by the Erciyes University of Faculty of Medicine Local Ethics Committee (approval no: 2012/58) and the Helsinki Declaration was taken into consideration and supported by the coordination of project unit (project no: TSU-12-3785). Detailed information was given about the study and approval was obtained.

\section{Inclusion Criteria for the Research}

- Having diagnosis of migraine according to International Classification of Headache Disorders-2 (ICHD-2),

- Age between 18 and 45 years,

- Voluntary for participation,

- Having any infectious, inflammatory and immunologic or autoimmune disease,

- Have not previously received any prophylaxis treatment or nonsteroidal anti-inflammatory drugs during the last one month,

- Not having an acute episode.

\section{Exclusion Criteria for the Research}

- Having cerebrovascular disease, intracranial mass, head trauma,

- Having an endocrinologic disease such as diabetes mellitus, thyroid hormone deficiency, Cushing's disease,

- Pregnancy, using hormonal antagonists or oral contraceptives,

- Having chronic disease, such as hypertension, heart disease, asthma, epilepsy and psychiatric disorder,

- Smoking and alcohol use,

- Menstruation or lactation period,

- Having the common carotid artery-intima-media thickness (CCA-IMT) values $>0.458 \pm 0.116 \mathrm{~mm}$ in males and $0.47 \pm 0.104$ $\mathrm{mm}$ in females.

In order to exclude possible risk factors for patients and serum levels of thyroid function tests, blood lipids, von Willebrand factor (VWF), and homocysteine levels were evaluated in the study. Insulin resistance was assessed using the homeostasis model assessment $=$ insulin resistance factor (HOMA-R) calculation, and endothelin and asymmetric dimethyl arginine (ADMA) were measured in the patient and control groups. Cerebral magnetic resonance imaging (MRI) was only performed in the patient group.

In order to assess endothelial function correctly in the study, the criterion was that had no attack in the last 15 days, because hemodynamic stability deteriorates during the attack period and 
the normal references of the blood parameters may change. In this study, we investigated the contribution of instability to the period without attack. The $10 \mathrm{~cm}$ Visual Analogue Scale (VAS) was used as to evaluate the pain intensity experienced by the patients (11). Using a ruler and "no pain" the score is determined based on the patient's subjective self-evaluation of pain, with a range of scores from 0 to 100 on the horizontal VAS (11).

\section{ADMA, Endothelin Level Measurement Sample Collection}

Serum and plasma specimens were separated by centrifugation at $3000 \mathrm{rpm}$ for $5 \mathrm{~min}$ from blood samples, and the serum portion was set aside for ADMA and kept for 3 months at $-80{ }^{\circ} \mathrm{C}$. The plasma sample was also stored at $-20{ }^{\circ} \mathrm{C}$ for endothelin. Tests for ADMA and endothelin were performed using enzyme-linked immunosorbent assay (ELISA) and statistically evaluated.

For the evaluation of other biochemical tests [glucose, cholesterol, triglyceride, high-density lipoprotein (HDL), insulin, VWF], 12-hour fasting blood samples were studied in the Erciyes University Faculty of Medicine central biochemistry laboratory. Low-density lipoprotein (LDL) levels were calculated using the Friedewald formula (LDL $=$ Total cholesterol-HDL-TG/5)

In terms of insulin resistance, HOMA-R = Serum glucose $\mathrm{mmol} / \mathrm{L} \mathrm{x}$ insulin micro $\mathrm{IU} / \mathrm{mL} / 22.5$ ) was used. Insulin resistance was considered positive if HOMA-R > 2.5.

\section{MRI Study}

A cerebral MRI examination was performed to exclude any intracranial lesions during the initial evaluation in patients who were scheduled to be included. MRIs were conducted using a Philips 1.5 Tesla Achieva Philips Netherlands ${ }^{\circledR}$. Patients were examined while in the supine position. Fluid-attenuated inversion recovery (FLAIR) sagittal, FLAIR axial, and T2W coronal and T2W axial images were taken. In patients with WMLs, the lesion load was assessed using the Fazekas scale:

\section{Periventricular WML:}

0: No lesion,

1: "Caps" or "pencil lining",

2: Round "halo",

3: Deep white area diffusion of irregular periventricular hyperintensities.

Deep WML:

0: No lesion,

1: Spot lesion,

2: Attachment tendency in lesions,

3: Wide-ranging hyperintense lesions.

\section{Ultrasonographic (USG) Method (FMD study)}

A high-resolution B-mode USG system with a linear transducer mid-frequency of $7.5 \mathrm{MHz}$ was used to determine FMD of the brachial artery. An experienced ultrasonographer who was blinded to the case and control groups performed all FMDs. At first, subjects rested in a lying position for $10 \mathrm{~min}$. Then, baseline brachial artery diameter was determined by locating the probe $4-5 \mathrm{~cm}$ above the antecubital fossa of the non-dominant arm. After that, a pneumatic tourniquet of a sphygmomanometer was inflated on the most proximal portion of the forearm to a pressure of $300 \mathrm{~mm} \mathrm{Hg}$ for $5 \mathrm{~min}$. After the cuff was released, a second scan was taken $30 \mathrm{~s}$ before and $90 \mathrm{~s}$ after cuff deflation and the average was measured. Artery diameters were determined with ultrasonic calipers from the leading edge of the anterior wall to the leading edge of the posterior wall of the brachial artery at the end of the diastolic period. Three other observers supervised the procedures. Changes in diameter were computed as a percentage relative to the baseline diameter.

FMD percentage is calculated using the following formula:

FMD $\%=(\mathrm{h} \max -\mathrm{b}) / \mathrm{b} \times 100$

Where h max equals the maximum diameter of the vessel, and b equals the measured baseline diameter (12).

The major advantages of this method are its non-invasiveness and reliability. It can be applied to asymptomatic persons for screening purposes. Studies conducted with this method have provided information on various risk factors for early atherosclerosis in childhood and young adults. The disadvantages of the test depend on the strength of the application and the experience of the person performing the USG $(13,14)$.

\section{USG Method (Carotid Intima Thickness)}

To assess the IMT, on a longitudinal, 2-D ultrasound image of the carotid artery, the anterior (near) and posterior (far) walls of the carotid artery are displayed as two bright white lines separated by a hypoechogenic space. We measured the IMT of the right common carotid artery just before the bifurcation three times and the average was taken as the value of IMT for our study. CCA-IMT, a structural marker of early atherosclerosis was increased in migraineurs, this elevation with patients and controls was excluded. According to a large-scale study on the same race performed in 2012, the CCA-IMT normal value was $0.458 \pm 0.116$ $\mathrm{mm}$ in males and $0.47 \pm 0.104 \mathrm{~mm}$ in females (15).

\section{Statistical Analysis}

The data were evaluated using the IBM Statistical Package for the Social Sciences Statistics 21 statistical package program. The Shapiro-Wilk test was used as the normal distribution test. The summary statistics of the variables with normal distribution are given as mean \pm standard deviation, and the summary statistics of normally non-distributed variables as median, and the $25^{\text {th }}$ percentile and $75^{\text {th }}$ percentile $[\mathrm{M}(\mathrm{Q} 1-\mathrm{Q} 3)]$. Student's t-test was used for normally distributed variables and the Mann-Whitney $\mathrm{U}$ test was used for non-parametric variables. The correlation between numeric variables was assessed using Spearman's correlation analysis and the exact test of the correlation between the categorical variables. $\mathrm{P}<0.05$ was accepted as statistically significant.

\section{Results}

According to the ICHD-2 diagnostic criteria, 51 patients with migraine without aura (8 males, $15.7 \%$; 43 females, $84.3 \%$ ) and 27 healthy controls (5 males, 18.5\%; 22 females, 81.5\%) were included in the study. There was no significant difference between the two groups in terms of demographic characteristics. The demographic characteristics of the patient and control groups are given in Table 1.

Biochemical blood parameters, HOMA-R index and endothelin and ADMA's serum levels and FMD measurement values in groups are shown in Table 2 and Figure 1. As illustrated in this table, the mean of FMD in the control group 
was dramatically higher than in the patients with migraine $(\mathrm{p}=0.021)$. As summarized in Table 2 and Figure 1, the ADMA and endothelin concentrations in both the case and control groups were not significantly different.

Of the patients who were included in the study, the brain MRI was normal in 11 patients and hyperintense lesions were found in 40 patients. When we calculated the stage of Fazekas, 30 patients were stage 1 (58.82\%, PVMLs and deep WMLs mostly), 5 patients were stage $3(9.8 \%)$, and 16 patients were stage $2(31.37 \%)$. Patients with MR lesions were staged according to the scale and are presented with various parameters on the MRI relationship in Table 3. As illustrated in this table, the HOMA-R in WMLs was dramatically higher than in the MRI normal patients $(\mathrm{p}=0.03)$.

There was a significant relationship between FMD and pain intensity, and WML in MRI. This is shown in Table 4. When the severity of pain increased, FMD, an indicator of endothelial dysfunction, also increased $(\mathrm{p}=0.001)$. A statistically significant correlation was found between brain hyperintense lesions and endothelial dysfunction ( $\mathrm{p}=0.004)$.

As endothelial dysfunction increases, hyperintense lesions in the brain are increasingly at increased risk. In addition, the

Table 1. Demographic characteristics of the participants

\begin{tabular}{|lcc|} 
& Patients & Controls \\
Female $(\mathrm{n} \%)$ & $43(84.3 \%)$ & $22(81.5 \%)$ \\
Male $(\mathrm{n} \%)$ & $8(15.7 \%)$ & $5(18.5 \%)$ \\
Total & 51 & 27 \\
Age $($ mean \pm SD) & $32.3 \pm 6.02$ & $35.04 \pm 8.52$ \\
BMI $\left(\mathrm{kg} / \mathrm{m}^{2}\right)$ & 24.5 & 23.9 \\
SD: Standard deviation & & \\
\hline
\end{tabular}
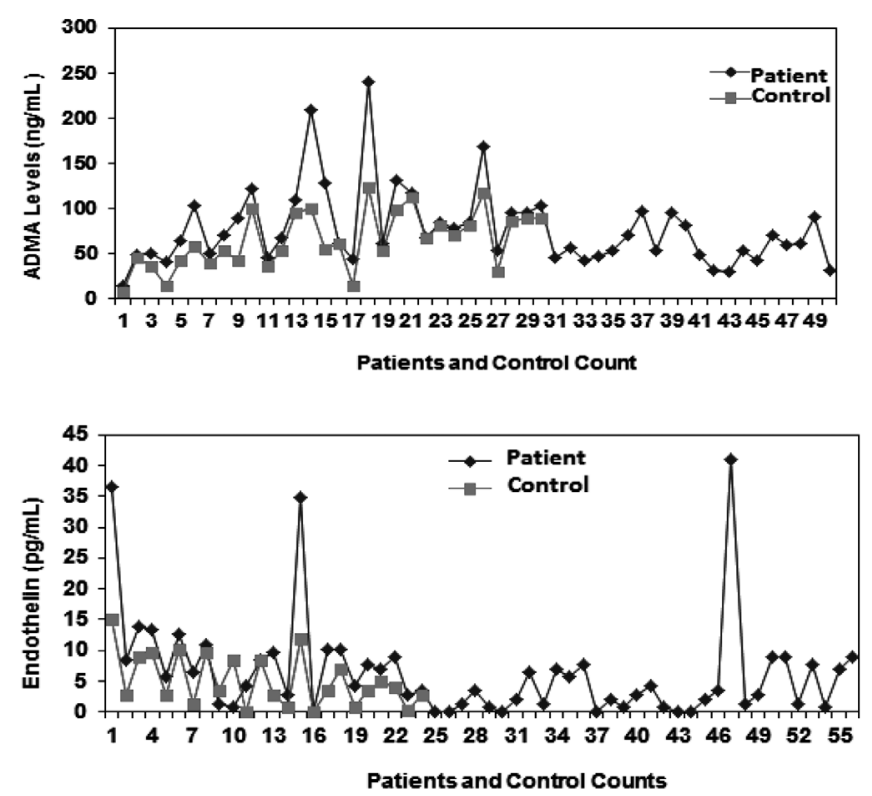

Figure 1. Asymmetric dimethyl arginine and endothelin values between the patient and control groups ADMA: Asymmetric dimethyl arginine increase in hyperintense lesions in the brain in our patient group did not increase the severity of pain $(\mathrm{p}=0.56)$.

When the blood parameters were evaluated with MRI lesion load, there was a positive correlation with age, cholesterol, LDL, body mass index, and triglyceride, and contrary to expectations, there was no relationship between homocysteine, height or the MR lesions of our study patients. However, there was a significant correlation between insulin resistance and lesion load $(\mathrm{p}<0.03)$.

\section{Discussion}

Migraine is a chronic, widespread, neurovascular disease. The pathogenesis of migraine has not been elucidated and different vascular, neurologic, and neuroinflammatory mechanisms play a role in its etiology $(13,14)$. Nitric oxide (NO) is responsible for trigeminovascular inflammation during migraine attacks (14). During migraine, endothelial NO and superoxide anions increase in the cerebral blood flow $(15,16)$.

In this study, the role of neurogenic inflammation, endothelial dysfunction, and oxidative stress in the pathogenesis of episodic migraine without aura was investigated and the relationship with white matter hyperintensities, which can occur as episodes, is discussed. We tried to emphasize which parameters were associated with hyperintense lesions in the brain.

\section{FMD, ADMA, Endothelin}

In our study, cerebral imaging was correlated with endothelial dysfunction markers in the time period without migraine attacks; there was a significant difference between the control group and

\begin{tabular}{|c|c|c|c|}
\hline & $\begin{array}{l}\text { Patients } \\
M\left(Q_{1}-Q_{3}\right)\end{array}$ & $\begin{array}{l}\text { Controls } \\
M\left(Q_{1}-Q_{3}\right)\end{array}$ & $\mathrm{p}$ \\
\hline Glucose & 80 & 76 & 0.281 \\
\hline Cholesterol & 170 & 168 & 0.713 \\
\hline Trygliceride & 130 & 120 & 0.281 \\
\hline LDL & 105 & 101 & 0.213 \\
\hline HDL & 42 & 44 & 0.041 \\
\hline TSH & 1.55 & 1.74 & 0.266 \\
\hline ST4 & 1.24 & 1.22 & 0.992 \\
\hline Homocystein & 14.6 & 12.6 & 0.068 \\
\hline $\mathrm{VWF}_{\text {antigen }}$ & 93.8 & 90.2 & 0.456 \\
\hline $\mathrm{VWF}_{\text {activity }}$ & 91.2 & 90.5 & 0.805 \\
\hline Ristocetin cof & 0.97 & 0.96 & 0.663 \\
\hline Basal insulin & 6.93 & 5.63 & 0.372 \\
\hline HOMA-R & 22.72 & 18.37 & 0.440 \\
\hline ADMA & 65 & 61 & 0.659 \\
\hline Endothelin & 3.55 & 4.05 & 0.566 \\
\hline FMD & 12.12 & 20 & 0.021 \\
\hline
\end{tabular}

LDL: Low-density lipoprotein, HDL: high-density lipoprotein, TSH: Thyroidstimulating hormone, VWF: Willebrand factor, HOMA-R: Homeostasis model assessment $=$ insulin resistance factor, FMD: Flow-mediated dilatation, ADMA: Asymmetric dimethyl arginine 
the patient group in the brachial artery USG using the FMD method $(\mathrm{p}=0.021)$. In our study, the control and patient groups were evaluated for pre-test; carotids with plaque or thickening were excluded because they are early stage atherosclerosis markers, so the patient and control groups matched. Subsequently, endothelial dysfunction was assessed with FMD and endothelial dysfunction was shown to be present in patients with migraine $(\mathrm{p}=0.021)$. In some previous FMD studies, the percentage of significance was higher in patients who had aura migraine. In the study conducted by Perko et al. (17), FMD was used to evaluate patients with migraine and there was no significant difference; it was discussed that the study was the measurement of carotid intima thickness. However, in a previous study by Rossato et al. (18), carotid IMT was significantly lower in patients with FMD migraine. In previous studies conducted to show endothelial dysfunction, the FMD response was found to be normal, sometimes diminished. The results of these studies differ from each other in

Table 3. Relationship between magnetic resonance imaging and various parameters

\begin{tabular}{|c|c|c|c|}
\hline & $\begin{array}{c}\text { MRI } \\
\text { normal }\end{array}$ & $\begin{array}{c}\text { MRI } \\
\text { WMLs }\end{array}$ & $\mathrm{p}$ \\
\hline Age & 33 & 41 & 0.160 \\
\hline BMI & 24 & 25.9 & 0.034 \\
\hline Glucose & 79 & 80 & 0.672 \\
\hline Cholesterol & 166 & 181.5 & 0.627 \\
\hline Triglyceride & 115 & 130 & 0.118 \\
\hline LDL & 105 & 105.5 & 0.992 \\
\hline HDL & 40 & 43.5 & 0.180 \\
\hline TSH & 1.54 & 1.55 & 0.720 \\
\hline ST4 & 1.24 & 1.23 & 0.899 \\
\hline Homocysteine & 13.5 & 15.5 & 0.126 \\
\hline $\mathrm{VWF}_{\text {antigen }}$ & 83.6 & 95.5 & 0.983 \\
\hline $\mathrm{VWF}_{\text {activity }}$ & 86.1 & 96.1 & 0.983 \\
\hline Ristocetin cof & 0.97 & 0.98 & 0.353 \\
\hline Basal insulin & 6.67 & 6.93 & 0.800 \\
\hline HOMA-R & 22.7 & 23.5 & 0.03 \\
\hline ADMA & 65 & 66.0 & 0.908 \\
\hline Endothelin & 2.84 & 6.03 & 0.147 \\
\hline
\end{tabular}

\begin{tabular}{|lccc|}
\hline $\begin{array}{l}\text { Table 4. Relationship of flow-mediated } \\
\text { white matter lesions and severity of pain }\end{array}$ & & \\
\hline & $\mathbf{n}$ & rho & p \\
FMD-brain lesions & 51 & 0.392 & 0.004 \\
FMD-severity of pain & 51 & 0.710 & 0.001 \\
Brain lesions-severity of pain & 51 & 0.462 & 0.56 \\
FMD: Flow-mediated dilatation & & & \\
\hline
\end{tabular}

that the frequency of the USG probe was between $7.5-10 \mathrm{MHz}$ at $14 \mathrm{MHz}$, significant performance was achieved in the episodic migraine group without aura. The most important point here is that the probe is scanned from the surface of the arterial wall of the smallest capillaries, which provides better resolution the higher the frequency (8).

Yetkin et al. (3) evaluated FMD and nitrate-stimulated FMD in their study to show endothelium-dependent and endotheliumindependent VD. FMD was found to be low in patients with migraine, with an increase in nitrate-dependent VD and a systemic abnormality in vascular tone control. The persistence of this disorder in the interictal period determined that the variability of vascular tone control was not limited solely to migraine attacks but was a persistent migraine phenomenon. As a result, the recurrence of migraine attacks leads to vascular endothelial dysfunction and migraine pain continues in the dysfunction. This suggests that migraine and vascular tone are mutually influential conditions (19).

In our study, endothelin and ADMA were evaluated, but no significant statistical correlation was found between them. No significant difference was found between the patient and control groups in terms of ADMA or endothelin values in our study. The reason for this may be the assessment of these markers in the interictal period. There was a significant change in FMD in the inter-episode period in our study; migraine attacks have been associated with dysfunction in endothelial cells, which results in an increasing amount of peroxynitrite and not ADMA and endothelin levels. Taffi et al. (20) and Uzar et al. (21) also obtained findings consistent with this study.

The level of endothelin was not statistically different between the patient and control groups, but it was found to be high in the patient group. Many previous studies have shown that antiendothelial antibodies are elevated and endothelial destruction begins because endothelial functions are not normal in patients with migraine (22) In Turkey, Yilmaz et al. (23) found high NO metabolites in patients with migraine with and without aura, but no statistical significance was observed.

\section{Migraine and Insulin Resistance}

Insulin resistance is a condition related to non-response at the peripheral receptor level, despite a normal amount of insulin, and is associated with conditions such as obesity, hypertension, and hyperlipidemia. The biologic effects of insulin resistance are related to abnormal fibrinolysis, hyperglycemia, hyperinsulinemia, systemic inflammation, hypertension, vascular endothelial dysfunction, and atherogenesis.

In our study, HOMA-R values were lower in the control group than in migraineurs, but there was no statistically significant difference. However, HOMA-R values were found to be significant for showing insulin resistance in patients with high WML load $(\mathrm{p}=0.03)$. Insulin receptor activation triggers headache in migraineurs, which is responsible for resistant headache (24).

Insulin resistance is associated with platelet aggregation, elevated serum VWF, and endothelial dysfunction. These abnormalities have been reported in pathogenesis in patients with migraine and may cause increased hypertension and stroke in migraineurs (25). In line agreement with our study, Rainero et 
al. (24) found that patients with migraine and healthy controls had high glucose levels and similar insulin levels. The authors discussed the role of high insulin levels in migraine pathogenesis and insulin receptor overstimulation in the brain and brain stem regions.

As a result of our work, practical suggestions can be presented in populations. We conclude that improving insulin resistance may also be beneficial for migraine. Aerobic exercises increase plasma endorphin levels, reduce the frequency of migraine attacks, and improve insulin resistance (26). A well-designed study for the role of insulin resistance in the pathogenesis of migraine may provide to the development of new treatment strategies in the future.

\section{Migraine and Stroke}

The incidence of hyperintense foci on white matter in T2weighted MRI scans in migraineurs is $5.5-46 \%$ (27). WMLs can also be seen in asymptomatic and healthy individuals. The clinical significance of the hyperintensity of the white matter is uncertain, and the pathogenesis of the lesions is multifactorial, although unclear. The pathophysiologic mechanism is considered to be the vasoconstriction caused by focal hypoperfusion during attacks $(28,29)$. Glutaminergic excitotoxicity, immunodeficient white matter demyelination, and other mechanisms are responsible for mitochondrial dysfunction in this process (30).

In our study, there was a positive correlation between the increased frequency of attacks in patients with migraine and FMD, and deep WMLs mostly. Any hyperintensities detected on MRI should not be associated with migraine. Osborn et al. (31) found that the rate of WMLs in migraineurs aged below 40 years was $5.5 \%$, but that the duration of disease and migraine complications in older patients with migraine might play a role in the appearance of lesions (32). Cooney et al. (29) found that the rate of WMLs in migraineurs was $6-16 \%$ according to age. A $12 \%$ prevalence of WML was detected in a study by Turkoglu et al. (32) involving migraine patients diagnosed with vasculitis test.

T2W hyperintense lesions may occur in migraineurs on MRI. These lesions are largely of ischemic origin, but there is no alternative hypothesis and assessment on this subject (33). Rocca et al. (34) found that the T2-lesion load was associated with frontal gray matter reduction. Researchers have described it as causing retrograde degeneration leading to macroscopic lesion formation (35).

One of the most important results that we achieved in our research shows that deep WML burden is increased in patients with endothelial dysfunction according to the brachial artery index. Positive correlations were found between attack frequency and severity and deep WMLs in patients with migraine without additional disease. However, similar correlations with age and LDL were achieved at the same time, which is one of the limitations of our study. Patients with elevated LDL cholesterol were excluded from the study, and the correlation of the other patients and lesion load was not statistically significant. Perhaps significant data would be obtained from larger population groups.

Our finding of endothelial dysfunction in patients migraine is an important scientific contribution to migraine etiopathogenesis. Non-invasive brachial artery USG in patients with migraine can provide important clues about endothelial dysfunction, and new treatment strategies can be developed. Another important finding in our study is that WMLs on MRI show ultrasonographic abnormalities in parallel. Along with many cases leading to white matter hyperintensity, it is important that this finding overlaps with USG findings and reinforces the classic theories in migraine pathophysiology.

\section{Study Limitations}

Among the limitations of our study, the patient population was small and the follow-up time was short; therefore, the parameters were not monitored longitudinally. In addition, the number of women in our study was high in comparison with the literature, and some of them may have affected the results because hormonal disorders can lead to endothelial dysfunction in the premenopausal period. Hormone tests have to be performed in order to determine the premenopausal period. These parameters were not examined because this was outside the scope of the study. These questions may be the subject of another study.

\section{Conclusion}

In conclusion, endothelial dysfunction in patients with migraine is an important finding in this study and it provides a scientific contribution to the development of new treatment alternatives. This study provides important data because other causes of endothelial dysfunction were excluded in order to understand the pathophysiology of migraine.

1. Significant statistical data were observed in the brachial artery index evaluated using FMD in the patient group.

2. No significant differences were observed in interictal thyroid hormones, blood lipid levels, insulin, HOMA-R index, ADMA, endothelin, VWF or homocysteine parameters.

3. There was a significant correlation between the number of deep WML numbers and pain severity and FMD index in MRI.

\section{Acknowledgement}

The authors are grateful for the financial support provided by the Unit of Scientific Research project no: TSU-2012-3785.

\section{Ethics}

Ethics Committee Approval: The study were approved by the Erciyes University of Faculty of Medicine Local Ethics Committee (approval no: 2012/58, project no: TSU-12-3785).

Informed Consent: Consent form was filled out by all participants.

Peer-review: Externally and internally peer-reviewed.

\section{Authorship Contributions}

Surgical and Medical Practices: H.S., Ş.B., S.G., R.S., Concept: H.S., A.T., Design: H.S., M.M., Data Collection or Processing: H.S., Analysis or Interpretation: H.S., Literature Search: H.S., Writing: H.S., M.M.

Conflict of Interest: No conflict of interest was declared by the authors.

Financial Disclosure: This study was approved by Ethics Committee (approval no: 2012/58) and the Helsinki Declaration was taken into consideration and supported by the coordination of project unit (project no: TSU-12-3785). 


\section{References}

1. Erdélyi-Bótor S, Aradi M, Kamson DO, et al. Changes of migraine-related white matter hyperintensities after 3 years: a longitudinal MRI study. Headache 2015;55:55-70.

2. Melhado EM, Bigal ME, Galego AR, Galdezzani JP, Queiroz LP. Headache classification and aspects of reproductive life in young women. Arq Neuropsiquiatr 2014;72:17-23.

3. Yetkin E, Ozışık H, Ozcan C, Aksoy Y, Turhan H. Increased dilator response to nitrate and decreased flow mediated dilatation in migraineurs. Headache 2007; $47: 104-110$

4. Chabriat H, Tournier-Lasserve E, Vahedi K, et al. Autosomal dominant migraine with MRI white-matter abnormalities mapping to the CADASIL locus. Neurology 1995;45:1086-1091.

5. Butt HJ, Franzmann U, Kruuse C. Endothelial function in migraine with aura- a systematic review. Headache 2015;55:35-54.

6. Windlansky ME, Gokce N, Keaney JF Jr, Vita JA. The clinical implications of endothelial dysfunction. J Am Coll Cardiol 2003;42:1149-1160.

7. Celermajer DS, Sorensen KE, Gooch VM, et al. Non-invasive detection of endothelial dysfunction in children and adults at risk of atherosclerosis. Lancet 1992;340:1111-1115.

8. Vernieri F, Moro L, Altamura C, et al. Patients with migraine with aura have increased flow mediated dilation. BMC Neurology 2010;10:18-24.

9. Larsen JS, Skaug EA, Wisløff U, et al. Migraine and endothelial function: The HUNT3 Study. Cephalalgia 2016;36:1341-1349.

10. Hamed SA. The vascular risk associations with migraine: relation to migraine susceptibility and progression. Atherosclerosis 2009;205:15-22.

11. Melzack R. The short-form McGill Pain Questionnaire. Pain 1987;30:191197.

12. Karvonen T, Matias T, Seppänen $T$, et al. Ultrasound image analysis for assessment of flow-mediated dilation of human arteries 2013;51(Supplement):R-249.

13. Silva FA, Rueda-Clausen CF, Silva SY, et al. Endothelial function in patients with migraine during the interictal period. Headache 2007;47:45-51.

14. Sarchielli P, Alberti A, Vaianella L, et al. Chemokine levels in the jugular venous blood of migraine without aura patients during attacks. Headache 2004; 44:961-968.

15. Beşir FH, Yazgan S, Celbek G, et al. Normal values correlates' of carotid intima- media thickness and affecting parameters in healthy adults Anadolu Kardiyol Derg 2012;12:427-433.

16. Yilmaz G, Surer H, Inan LE, Coskun O, Yucel D. Increased nitrosative and oxidative stress in platelets of migraine patients. Tohoku J Exp Med 2007;211:23-30.

17. Perko D, Oblak J, Sabovic M, Zvan B, Zaletel M. Endotelium dependent vasodilatation in migraine patients. Cephalalgia 2011;31:654-660.
18. Rossato A, Veronese F, Maggioni F, et al. Autonomic dysfunction and endothelial changes in migraine sufferers. Panminerva Med 2011;53:13-18.

19. Schwedt TJ. Endothelial dysfunction in migraine. Cephalalgia 2009;29:9971002.

20. Taffi R, Vignini A, Lanciotti C, et al. Platelet membrane fluidity and peroxynitrite levels in migraine patients during headache-free periods. Cephalalgia 2005;25:353-358.

21. Uzar E, Evliyaoglu O, Toprak G, et al. Increased asymmetric dimethylarginine and nitric oxide levels in patients with migraine. J Headache Pain 2011;12:239-243.

22. Vanmolkot FH, Hoon J. Endothelial function in migraine: a cross-sectional study BMC Neurology 2010;10:119.

23. Yılmaz G, Sürer H, Coşkun Ö, İnan L, Yücel D. Plasma Nitric Oxide Metabolites in Migraine with and without Aura. Turkish Journal of Biochemistry-Turk J Biochem 2005;30:236-240.

24. Rainero I, Limone P, Ferrero M, et al. Insulin sensitivity is impaired in patients with migraine. Cephalalgia 2005;25:593-597.

25. Guldiken B, Guldiken S, Taskiran B, et al. Migraine in metabolic syndrome. Neurologist. 2009;15:55-58.

26. Köseoğlu E, Akboyraz A, Soyuer A, Ersoy AÖ. Aerobic exercise and plasma beta endorphin levels in patients with migraneous headache without aura. Cephalalgia 2003;23:972-976.

27. Tietjen GE, Herial NA, White L, et al. Migraine and biomarkers of endothelial activation in young women. Stroke 2009;40:2977-2982.

28. Kruit MC, Launer LJ, Ferrari MD, van Buchem MA. Brain stem and cerebellar hyperintense lesions in migraine. Stroke 2006;37:1109-1112.

29. Cooney BS, Grossman RI, Farber RE, Goin JE, Galetta SL. Frequency of magnetic resonance imaging abnormalities in patients with migraine. Headache 1996;36:616-621.

30. Trauninger A, Ossy EL, Kamson DO, et al. Risk factors of migraine-related brain white matter hyperintensities: an investigation of 186 patients. $\mathrm{J}$ Headache Pain 2011;12:97-103.

31. Osborn RE, Alder DC, Mitchell CS. MR imaging of the brain in patients with migraine headaches. AJNR Am J Neuroradiol 1991;12:521-524.

32. Turkoglu R, Arsan F, CetinkayaY, Orken C, Tireli H. Migrenlilerde Ak Madde Lezyonlarının Prevalansı. Düsünen Adam 2004;17:39-42.

33. Dodick DW, Roarke MC. Crossed cerebellar diaschisis during migraine with prolonged aura: a possible mechanism for cerebellar infarction. Cephalalgia 2007;28:83-86.

34. Rocca MA, Pagani E, Colombo B, et al. Selective diffusion changes of the visual pathways in patients with migraine: a $3 \mathrm{~T}$ MRI study. Stroke 2008;28:1061-1068.

35. Szabó N, Kincses ZT, Párdutz A, et al. White matter microstructural alterations in migraine: A diffusion-weighted MRI study. Pain 2012;153:651656. 